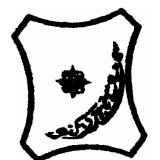

Bayero Journal of Pure and Applied Sciences, 7(2): 150 - 154

Received: August 2014

Accepted: November 2014

ISSN $2006-6996$

\title{
EFFECT OF BROOD STOCK SIZE ON EGG FERTILIZATION, HATCHABILITY AND FRY SURVIVAL RATE OF AFRICAN CATFISH (CLARIAS GARIEPINUS)
}

\author{
${ }^{1}$ Bichi, A.H., ${ }^{2}$ Isyaku, S., ${ }^{3}$ Danba, E.P., ${ }^{2}$ Kurawa, I.A., and ${ }^{2}$ Nayawo, A.A. \\ ${ }^{1}$ Department of Biological Sciences, Bayero University, Kano, Nigeria \\ ${ }^{2}$ Department of Agricultural Science Education, Sa'adatu Rimi College of Education, Kumbotso, P.M.B. 3218, Kano \\ ${ }^{3}$ Department of Biological Sciences, Taraba State University, P.M.B. 1167, Jalingo, Taraba State, Nigeria \\ Correspondence author: ishaqibu@yahoo.com
}

\begin{abstract}
This experiment was conducted to investigate the effect of size of brood stock on egg fertilization, hatchability and fry survival rate of Clarias gariepinus in an intensive culture system, for a period of four weeks. Larger brood stock size (1200-1500g) produced larger eggs and bigger fry while moderate brood stock size (795-1000)g produced moderate eggs and moderate fry. The mean size of eggs produced and the size of brood stock was however not significantly different $(p>0.05)$. In addition, larger eggs resulted in larger fry. The survival rate of fry after starvation increased with increase in parent brood stock size. Best on this study it was recommended that for larger eggs and fry production, brood stock of Clarias gariepinus, of average size of (1200-1500g) should be selected for use in fish hatchery operation in Nigeria. There was no significant difference $(p>0.05)$ in the physiochemical parameters.
\end{abstract}

Keywords: Broodstock, Egg fertilization, Hatchability, Clarias gariepinus

INTRODUCTION

As the world population increases, the demand for fish in the world also grow, in spite of high preference for fish and fisheries products in Africa, the per capita consumption of fish in this part of the world is still very low FAO (2000). Clarias gariepinus and Heterobranchus species are the two commonly cultured Clariid fish (Vanden and Bernacsek, 1990; Ojutiku, 2008). They are reared all-over the country especially in the south and have very good commercial value in Nigeria markets (Adewolu and Adoti, 2010; Owodeinde and Ndimele, 2011). Methods of artificial seed propagation of African catfish (Clarias gariepinus) are very expensive in Nigeria and hatchery operators are usually scared of big size of brood stock not just because of the large quantities of spawning hormone that will be required for induced breeding exercise, but also because of their high price Sule and Adikwu ( 2004). The species in this family do not breed readily in captivity and productivity in the wild is usually very low, thus making fingerling collection from the wild not only time consuming and labour intensive but also very uncertain. Therefore, there has been a particular interest in examining the effect of brood stock and egg size of fry and fingerling since it affects fecundity of fish species (McGinley and Charvon, 1988). Clarias gariepinus exhibit considerable variability in egg size, both within and among populations. This is accounted for by female age and size (Richter and VandenHurk 1982) inter population variability in egg size could be due to environmental differences with large egg size of female fish. The reproductive strategies that concern offspring size and number could vary among population while differences in parental size could also account for some variations in the fry development process. Though, several authors have studied feeding effects on fecundity in fishes (Bagenal; 1969a; Knox et al. 1998, Sule and Adikwu 1999) however, the range of brood stock sizes that will produce maximum size of good quality eggs and larvae high survival rate has not been extensively investigated. The aim of this research is to identify the effect of brood stock size on egg fertilization, hatchability and fry survival rate of $C$. gariepinus.

\section{MATERIALS AND METHODS}

Experimental Fish and Hormone Injection

The experiment was conducted at Fangam integrated Fish farm at Mariri in Kumbotso Local Government area, Kano State. Matured Males and Females of $C$. gariepinus sizes range from (700-1500)g were procured for the experiment from fangam integrated farm and stock in concrete tanks size of $2 \mathrm{~m}^{2}$ at the hatchery complex. 15Males and Females fish were selected eachand group into two according to sizes and the females brooder were injected with Human Gonadotropin hormone (trade mark: Ovaprim) at dosage of $0.5 \mathrm{ml}$ per kilogram $(\mathrm{kg})$ of fish body weight and the injection was done intramuscularly under the pectoral fin or at the neck. The injected area was rubbed with a finger in order to distribute the Ovaprim hormone evenly throughout the muscle and to prevent backflow of the Ovaprim hormone. The injected fish were kept in well aerated water in a small tank. The temperature of the water holding the fish was measured with mercury in glass thermometer and the corresponding latency times were taken and the milt used was collected by sacrificing the males. The male was dissected using a sharp razor blade and the testes were removed, cleaned off the blood with a tissuepaper and kept in a plastic bowl with a saline solution until needed. Incision was made into the creamy coloured lobes of the testes and the milt was squeezed out of the testes sac with physiological solution. The injection took place between $8.00 \mathrm{pm}$ and $9.00 \mathrm{pm}$. 


\section{Stripping and Egg size Determination}

At the expiration of the latency period, the females were carefully removed and hand stripped manually for eggs. The body of the female brooder was moped with a towel; this was done to prevent the eggs from coming in contact with water, which may consequently seal up micropyle and prevent fertilization. Slight pressure was applied on the abdomen of the female brooder, and this led to the ovulated eggs oozed out easily from the genital opening which were collected in plastic bowl. A sample of 20 unfertilized eggs from each Female size class was taken to determine egg sizes. Measurement of diameter of egg was made to the nearest $0.01 \mathrm{~mm}$ with a microscope with an ocular micrometer. The mean weight of egg batches of eggs and the mean weight of 150 fry from the brood stock sizes were determined.

\section{Egg size relationship}

Fertilized egg batches from both large brood stock size(1200-1500)g and small brood stocd size (795-1000) were reared separately in tanks of (300 x $300 \times 400) \mathrm{cm}$ with from through system starting from the third day after hatching. The fry were fed with Atermia three times daily for three weeks

\section{Performance of starved fry}

Trials to assess how starvation affected the survival of fry were conducted in replicate after the absorption of egg yolk for 150 fry from each brood stock size group. The fry were starved for seven days and the percentage survival of fry after starvation was determined for each size group.

\section{Physiochemical parameters}

The surface water temperature was determined using mercury in glass thermometer. The thermometer was placed vertically until the bulb containing the mercury is inside the water, for about five minutes the reading was taken and recorded in degree centigrade (APHA, 1992).

The $\mathrm{PH}$ of water was determined using $\mathrm{PH}$ digital meter model $\mathrm{Ts}^{-1}$ jafan before starting the measurement the meter was standardized with potassium hydrogen titrate buffer solution then the $\mathrm{PH}$ meter was switched on and the electrodes were dipped inside the sampled water and readings were taken (Ademorati, 1996)

This was carried out by the use of Winkler's titration method (Ademorati, 1996). At the experimental site water was sampled into a $300 \mathrm{ml}$ bottle and $2 \mathrm{ml}$ of manganoustetraoxosulphate vi $\left(\mathrm{MnSO}_{4}\right)$ solution was added and $2 \mathrm{ml}$ of alkali Iodine-azide reagent well below the surface were added, a stopper was put this was to exclude air bubbles. On reaching the laboratory, this was mixed by inverting the bottle many times later clear supernatant water was obtained and this was allowed to settle. After 2 minutes, $2 \mathrm{ml}$ of concentrated tetraoxosulphatevi was added and this mixed until dissolution was completed. A total of $250 \mathrm{ml}$ was titrated against $0.012 \mathrm{ml}$ Sodium thiosulphate until a pale straw colour lead paint was observed. Then $1 \mathrm{ml}$ starch solution was added the colour becomes blue. The titration was continued by the addition of the Sodium thiosulphate solution in drops, until the blue colour disappeared. The dissolve oxygen was then calculated using the following formular:

$$
D 0 \mathrm{mg} / l=\frac{1600 \mathrm{~mm} x \mathrm{v}}{(\mathrm{v}-2.0)}
$$

Statistical analysis: The data collected were analyzed for significant differences $(P<0.05)$ by Analysis of variance (ANOVA) and Pearson Correlation using computer statistical package for social sciences (SPSS) for windows (V.15.0).

\section{RESULTS}

The effect of brood stock size on egg and larval size of C. gariepinus is show in Table 1 . The weight of eggs produced increased with increase in brood stock sizes. The lowest weight of egg production was from brood stock size of $795 \mathrm{~g}$ while the highest weight of egg production was recorded from of $(1200-1500) \mathrm{g}$ size range. There was however, no significant difference $(P>0.05)$ between the mean weight of eggs produced from the brood stock size range. The size of fry produced also increased with increase in brood stock sizes. The smallest fry was produced by the smallest brood stock size range(795 -1000)g, while the largest fry size was produced by the largest brood stock size range $(1200-1500) g$. There was however a significant differences $(P<0.05)$ between the fry size produced by small brood stock size range (795- 1000)g and the large brood stock size $(1200-1500) \mathrm{g}$ of $C$. gariepinus. In addition, larger eggs resulted in larger fry. The size fry increased with corresponding increase in brood stock size.

Table2, Shows the effect of egg size on survival potential of Clariasgariepinus fry starved for one week. The size of the parent brood stock varies from $795-1500 \mathrm{~g}$ while the corresponding mean egg size range from $1.00-1.6 \mathrm{~mm}$ while the mean weight of eggs batches obtained from the female brood stock ranged from $14.4-30.1 \mathrm{~g}$. The survival rate of fry after starvation increased with increase in parent brood stock size. The highest fry survival (60-90\%) was recorded for the highest brood stock size (1200 $1500) g$ while the lowest fry survival rate $(50 \%)$ was recorded for the lowest brood stock size $(795 \mathrm{~g})$. Table 3 , shows that laboratory water temperature ranged from $25.9^{\circ} \mathrm{c}-30^{\circ} \mathrm{c}$ with mean of $27.93 \pm 1.49$ during the period of the experiment. The dissolved oxygen (DO) ranged between $5.0 \mathrm{mg} / 1-5.6 \mathrm{mg} / \mathrm{l}$ with mean of $5.24 \pm 0.62$. The $\mathrm{pH}$ ranged between $6.10 / 7.0$ with mean $6.5 \pm 0.35$. 
Table 1: Effect of varying egg size on percentage fertilization and Hatchability of Clariasgariepinus

\begin{tabular}{|c|c|c|c|c|c|c|c|c|c|}
\hline $\begin{array}{l}\text { Mean } \\
\text { size of } \\
\text { Egg } \\
(\mathrm{mm})\end{array}$ & $\begin{array}{l}\text { Mean } \\
\text { wt. of } \\
\text { female } \\
\text { spawner } \\
\text { (g) }\end{array}$ & $\begin{array}{l}\text { Mean } \\
\text { Latency } \\
\text { Time } \\
\text { (h) }\end{array}$ & $\begin{array}{l}\text { Mean } \\
\text { water } \\
\text { Tempt. } \\
\left({ }^{\circ} \mathrm{C}\right)\end{array}$ & $\begin{array}{l}\text { Mean } \\
\text { wt. of } \\
\text { eggs } \\
\text { stripped } \\
\text { (g) }\end{array}$ & $\begin{array}{l}\text { Mean no. } \\
\text { of Est. } \\
\text { eggs milt } \\
(1 \mathrm{~g}=700)\end{array}$ & $\begin{array}{l}\text { Mean } \\
\text { no. of } \\
\text { eggs } \\
\text { fertilized }\end{array}$ & $\begin{array}{l}\text { Mean \% } \\
\text { of eggs } \\
\text { fertilized }\end{array}$ & $\begin{array}{l}\text { Mean } \\
\text { no. of } \\
\text { fry } \\
\text { hatch } \\
\text { out }\end{array}$ & $\begin{array}{l}\text { Mean \% } \\
\text { hatchability }\end{array}$ \\
\hline 1.1 & 800 & 7 & 28.9 & 14.4 & 10080 & 6575 & 65.2 & 6355 & 96.7 \\
\hline 1.6 & 1447 & 8 & 29.1 & 17.8 & 12460 & 8244 & 66.2 & 6117 & 74.2 \\
\hline 1.2 & 899 & 9 & 29.4 & 20.3 & 14187 & 10221 & 72.1 & 8567 & 83.8 \\
\hline 1.6 & 1499 & 10 & 29.8 & 28.1 & 19647 & 14895 & 75.7 & 13200 & 88.8 \\
\hline 1.4 & 1299 & 11 & 29.8 & 26.3 & 18387 & 9952 & 54.1 & 8583 & 86.3 \\
\hline 1.2 & 1098 & 12 & 29.6 & 24.3 & 16987 & 8302 & 48.9 & 7000 & 84.6 \\
\hline 1.3 & 1198 & 13 & 29.3 & 25.1 & 17547 & 6983 & 39.8 & 6183 & 88.6 \\
\hline 1.2 & 1000 & 14 & 29.7 & 22.9 & 16053 & 3693 & 23.0 & 2867 & 77.7 \\
\hline 1.5 & 1401 & 15 & 29.8 & 30.1 & 21047 & 4533 & 21.5 & 3950 & 87.1 \\
\hline 1.3 & 1249 & 16 & 29.6 & 27.5 & 19227 & 0.00 & 0.00 & 0.00 & 0.00 \\
\hline
\end{tabular}

Table 2: Showing effect of Egg size on survival potential of Clariasgariepinus fry starved for one week

\begin{tabular}{llllllll}
\hline S/NO & $\begin{array}{l}\text { Size } \\
\text { broodstock } \mathbf{( g )}\end{array}$ & $\begin{array}{c}\text { range } \\
\text { (mm) }\end{array}$ & $\begin{array}{l}\text { mean egg size } \\
\text { (megg } \\
\text { eg) }\end{array}$ & $\begin{array}{l}\text { wt. of } \\
\text { batches }\end{array}$ & $\begin{array}{l}\text { No of } \\
\text { starved }\end{array}$ & $\begin{array}{l}\text { fry } \\
\text { after } \\
\text { week }\end{array}$ \\
\hline 1 & $800-900$ & $1.1 \pm 0.21$ & $14.4 \pm 0.82$ & 150 & 50 & 55 \\
2 & $1000-1090$ & $1.2 \pm 0.18$ & $24.3 \pm 0.50$ & 150 & 60 \\
3 & $1100-1190$ & $1.3 \pm 0.16$ & $25.1 \pm 0.40$ & 150 & 70 \\
4 & $1200-1290$ & $1.4 \pm 0.13$ & $26.3 \pm 0.36$ & 150 & 90 \\
5 & $1400-1500$ & $1.6 \pm 0.10$ & $28.1 \pm 0.22$ & 150 & & 90 \\
\hline
\end{tabular}

Table 3. Water quality parameters in the experimental fish holding facilities

\begin{tabular}{cccc}
\hline & Temperature $\left({ }^{\circ} \mathbf{C}\right)$ & Dissolved Oxygen $\mathbf{( m g / l )}$ & $\mathbf{P}^{\mathbf{H}}$ \\
\hline 25.9 & 5.0 & 6.10 \\
& 26.2 & 5.1 & 6.17 \\
26.6 & 5.2 & 6.20 \\
27.1 & 5.4 & 6.36 \\
27.4 & 5.2 & 6.19 \\
28.4 & 5.3 & 6.40 \\
& 28.6 & 5.5 & 6.45 \\
Total & 29.4 & 5.0 & 6.82 \\
Mean & 29.6 & 5.1 & 6.98 \\
& 27.0 & 5.6 & 7.00 \\
& $27.92 \pm 1.49$ & 52.4 & 65.0 \\
\hline
\end{tabular}

\section{DISCUSSION}

The result of brood stock, egg and fry size relationship from this investigation shows that the weight of eggs produced increased with increase in brood stock size. Larger eggs were produced by larger brood stock, while small eggs came from smaller females of $C$. gariepinus. Roff, (1992) reported similar results from his study of brood stock and egg relationship in Clarias gariepinus, in fact, egg size determined most of the variation in final juvenile fitness, as larger eggs came from larger females. This could be due to larger yolk reserve or they could also have inherited higher growth rates from the start of external feeding.

The size of fry produced from this study increased with increase in brood stock size. The smallest size of fry was produced by the smallest brood stock size while larger eggs resulted in larger fry. The size of fry increased with corresponding increase in egg size. This could be due to large egg yolk reserve in large eggs and this is in line with Size of fry at hatching been reported to be positively correlated with egg size in most of the studies fish species (Bagenal,1969b; Spingate and Bromage, 1985; Marsh, 1986 and Hutching's; 1991).

As shown in the result, the survival rate of fry of $C$. gariepinus after starvation increased with increase in parent brood stock size. The survival rate of fry was high in large brood stock size while the lowest survival rate of frywas obtained for the small brood stock size. This was supported by an earlier study by Marsh, (1986), and Miller et al. 1988 where larger fry at hatching were noted to have some advantages in survival and fitness.

The physico-chemical parameters of a body of water is very important to the productivity, growth and survival of the aquatic organisms that are living in the water and thus play an important role in the biology and physiology of the fishes which are part of the organisms living in water (Adebisi, 1981). 
Temperature $\left({ }^{0} \mathrm{C}\right)$ values ranged between 25.9 and $30^{\circ} \mathrm{C}$ were recorded in the experiment and this is in line with (Ayinla, 1988), which reported that the time of interval between the start of embryonic development (fertilization) and hatching, (incubation period) changes with the increase in temperature, Adeniji and Ovie (1982) and Madu (1989), reported that the best temperature range for optimum production of Clarias species is $25-31^{\circ} \mathrm{C}$, Afzal et al., (2007) recommended a temperature range of between 25 to $32^{\circ} \mathrm{C}$ for good performance of fishes. The $\mathrm{PH}$ of the water ranged from 6.1 to $.6 \mathrm{PH}$ and this is in agreement with the world health organization. International standard for the fresh water is of 7.08.PH. It also corresponds with works ofHuet (1972), USDA, (1996), and Robert, (2007), which indicate that the best water for cultivation is that which is neutral or slightly alkaline with a $\mathrm{PH}$ range of 7 to 8 .

The value for dissolved Oxygen content of water ranged from $5.0 \mathrm{mg} / \mathrm{l}$ and these agreed with those Ufodike and Garba (1992) a minimum constant value

\section{REFERENCES}

Adebisi, A.A., 1981. The physic-chemical Hydrobiology of seasonal upper river, Hydrobiology 79:157-165.

Ademorate, C.M.A., 1996. Standard methods for water and effluents Analysis pg 20-27

Adeniji, H.A, Ovie S.L., (1982). Study and appraisal for water quality of the Asaoli and Niger rivers. NIFFR Annual report pp. 15-20

Afzal, M.; Rab, A.; Akhtar, N.; Khan, M.F.; Barlas, A. and Qayyum, M. (2007). Effect of organic and inorganic fertilizers on the growth performance of bighead Carp Aristichthysnobilis) in polyculture system international journal of Agriculture and Biology, 9(6): 931-933

APHA, 1992. Standard method for the examination of water and waste water, $15^{\text {th }}$ edition American public health Association Washington, D.C., PP134

Ayinla, O.A., 1988. Nutrition and Reproductive performance of Clariasgariepinus (Burchell 1822), Ph.D Thesis, Department of wildlife and fisheries Management, University of Ibadan Nigeria, pp: 433

Adewolu, M.A. and A.J. Adoti, 2010. Effect of mixed feeding schedules with varying dietary crude protein levels on the Growth and feed utilization of Clariasgariepinus (Burchell,1822) fingerlings. J. fish. Aquat. sci., 5: 304-310

Bagenal, T.B., 1969a. Relationship between food supply and fecundity in brown trout salmoTrultaL.J.Bio.1:167-182

Bagenal, T.B., 1969b. Relationship between egg size and fry survival in brown trout Salmotrulta L.J.Bio.1:349353.

Brain, O., 2006. Dissolved Oxygen Environmental quality 84: 18766 of $4.0 \mathrm{mg} / \mathrm{l} \mathrm{DO}$ is adequate for most species and stages of aquatic life and Brain (2006) and Ita et al., (1995), that reported increased DO level is needed to support an increase in metabolic rates and reproduction.

\section{SUMMARY AND CONCLUSION}

In practicing fish breeding therefore, it is better to select brood stock of average size of $0.8-1.6 \mathrm{~kg}$. This is due to the fact that femaleClariasgariepinus in this range could produce larger eggs whose larvae could endure starvation better and reach a point of return later than species that below $0.5 \mathrm{~kg}$ which produce smaller eggs and subsequent smaller larvae. Catfish farming has continued to attract private sector initiative compared to earlier public or government sponsored programmed and if the associated problems of production, especially the twin issue of feeds production and fingerling supply are tackled, Nigeria will soon become a world exporter of Catfish.

Food and Agriculture Organization (F.A.O.) fishery statistics: Catches and landing. FAO year book 1995; 74:549pp.

Food and Agriculture Organization: FAO Aquaculture newsletter April 2000; 24 - 37.

Huet, M.,(1972). Textbook of fish culture breeding and cultivation of fish translated by $\mathrm{H}$. Kohn fishing news (books) Ltd, farnham, survey England pp436

Hutching, J.A., 1991. Fitness consequencies of variation in Egg size and food abundance in brook trout salvelinusfontinalis, Evolution 45:1162-1168

Ita, E.O., Balogun, J.K., Adimula A.B., (1995). A preliminary report of pre-impoundment of fishe survey of Goronyo reservoir Sokoto. NIFFR Annual report Pp35-38

Knox, D., Bromage, N.R., Cowey, C.B. and Springate, J.R.C., 1988. The effect of broodstock ration size on the composition of rainbow trout eggs (Salmogairdineri). Aquaculture, 69:93104

Madu, C.T.,(1989).Hatchery management of the mudfish, Clariasanguilaris (L) Ph. D. thesis

Marsh, E. 1986. Effect of egg size of offspring fitness and maternal fecundity in the orange-throat darter Etheostomaspectabile (Pisces: percidae). Copeia. 1986: 18-30

Miller, T.J., Crowder, L.B. Rice J.A. and Marshall, E.A., 1988. Larval size and recruitment mechanisms in fishes: Toward a conceptual frame work can. J.F. Aquat. Sci. 45: 16571670.

McGinley, M.A., and Charnov, E.Z., 1988. Multiple resources and Optimal balance between size and number of offspring. Evol. Ecol. 2: 77-84

Ojutiku, R.O., 2008. Comparative survival and growth rate of Clariasgariepinus and Heteroclarias, hatchlings fed live and frozen daphnia. Pak. J. Nutr., 7:527-529 
Owodeinde, F.G. and P.E. Ndimele, 2011. Survival, growth and feed utilization of two Clariid Catfish (Clarias garierpinus, Burchell1822 and Heterobranchus bidorsalis, Geoffroy, 1809) and their reciprocal hybrids. J. Applied Ichthyol, 27:1249-1253

Richter, C.J.J. and A.J. Van Der Hurk, 1982.Effect of ii esocorticosterone-acetate and carp pituitary suspension of follicle maturation in the Ovaries of African Catfish Clariaslazera (C and V). Aquaculture, 29: 53-66.

Robert, C.S., 2007. Water quality consideration for Aquaculture.J. Animal Ecol, 2: 1-15

Roff, D.A.,1992. The Evolution of life history. Champman and Hall, New York., 535pp.

Springate, J.R.C. and Bromage, N.R., 1985. Effect of egg size on early growth and survival in rainbow trout (Salmon gairdneri Richardson) Aquaculture, 47: 163-172

Sule, O.D. and Adikwu, I.A., 1999. Effect of dietary protein levels on Ovary development and Fecundity in Clarias gariepinus. Journal of experimental Biology 4: 39-43

Sule, O.D. and Adikwu, I.A., 2004. Effect of brood stock size on egg and larval size and survival of larvae of African Catfish, C. gariepinus under laboratory conditions. Journal of Aquatic sciences 19(1) 1-4
Ufodike, E.B. and Garba, A.J. (1992). Seasonal variation in Limnology and productivity of a tropical highland fish pond in Jos Plateau, Nigeria journal of Aquatic sciences, 7:29-34

USDA, US Department of Agriculture (1996). Aquaculture outlook, the rev. 4: 26-28

VandenBossche, J.P., G.M. Bernacsek, 1990. Source book for the inland fishery resource of Africa. Food and Agriculture organization of the United Nations, Rome, Italy, ISBN13:9789251029831, page: 424 